\title{
Bacteria causing important diseases of citrus utilise distinct modes of pathogenesis to attack a common host
}

\author{
Adrián Alberto Vojnov • Alexandre Morais do Amaral • \\ John Maxwell Dow • Atilio Pedro Castagnaro • \\ Marìa Rosa Marano
}

Received: 21 February 2010 /Revised: 14 April 2010 / Accepted: 15 April 2010 /Published online: 7 May 2010

(C) Springer-Verlag 2010

\begin{abstract}
In this review, we summarise the current knowledge on three pathogens that exhibit distinct tissue specificity and modes of pathogenesis in citrus plants. Xanthomonas axonopodis pv. citri causes canker disease and invades the host leaf mesophyll tissue through natural openings and can also survive as an epiphyte. Xylella fastidiosa and Candidatus Liberibacter are vectored by insects and proliferate in the vascular system of the host, either in the phloem (Candidatus Liberibacter) or xylem (X. fastidiosa) causing variegated chlorosis and huanglongbing diseases, respectively. Candidatus Liberibacter can be found within host cells and is thus unique as an intracellular phytopathogenic bacterium. Genome sequence comparisons have identified groups of speciesspecific genes that may be associated with the particular lifestyle, mode of transmission or symptoms produced by each phytopathogen. In addition, components that are conserved amongst bacteria may have diverse regulatory
\end{abstract}

A. A. Vojnov $(\bowtie)$

Instituto de Ciencia y Tecnología "Dr. Cesar Milstein",

Fundación Pablo Cassará,

Consejo Nacional de Investigaciones Científicas

y técnicas (CONICET),

Saladillo 2468,

C1440FFX Buenos Aires, Argentina

e-mail: avojnov@fundacioncassara.org.ar

A. Morais do Amaral

Embrapa Recursos Genéticos e Biotecnologia,

CP 02372 ,

70770-917 Brasília, Federal District, Brazil

A. Morais do Amaral

Centro de Citricultura Sylvio Moreira,

CP 04,

13490-970 Cordeiropolis, São Paulo, Brazil actions underpinning the different bacterial lifestyles; one example is the divergent role of the Rpf/DSF cell-cell signalling system in $X$. citri and $X$. fastidiosa. Biofilm plays a key role in epiphytic fitness and canker development in $X$. citri and in the symptoms produced by $X$. fastidiosa. Bacterial aggregation may be associated with vascular occlusion of the xylem vessels and symptomatology of variegated chlorosis.

\section{Keyword Citrus}

\section{Introduction}

Xanthomonas axonopodis pv. citri, Xylella fastidiosa and Candidatus Liberibacter asiaticus are bacteria that infect citrus plants, causing citrus canker disease (CCD), citrus variegated chlorosis (CVC) and huanglongbing (HLB),

\footnotetext{
J. M. Dow

BIOMERIT Research Centre, Department of Microbiology, National University of Ireland,

Cork, Ireland

\section{A. P. Castagnaro}

Sección Biotecnología de la Estación Experimental Agroindustrial Obispo Columbres-UA-INSIBIO (CONICET-UNT),

Casilla No. 9, Las Talitas,

4101 Tucumán, Argentina

M. R. Marano

Instituto de Biología Molecular y Celular de Rosario (IBR-CONICET), Área Virología, Facultad de Ciencias

Bioquímicas y Farmacéuticas,

Universidad Nacional de Rosario,

Suipacha 531,

2000 Rosario, Argentina
} 
respectively. These diseases greatly reduce production, eventually causing death of the infected trees, with substantial economic impact. HLB is the most destructive disease of citrus worldwide (Bove 2006; Stokstad 2006; Callaway 2008) and because of the major outbreaks of the HLB that started in Brazil (in 2004) and USA (in 2005), these countries have already removed tens of millions of trees, with an impact of billions of dollars since its occurrence alone. $X$. citri and $X$. fastidiosa are related organisms that belong to the $\gamma$ subdivision of the Proteobacteria in the family of Xanthomonadaceae. $\mathrm{Ca}$. Liberibacter asiaticus in contrast belongs to the order Rhizobiales in the $\alpha$-subdivision of the Proteobacteria (Doddapaneni et al. 2008) and is closely related to members of the Rhizobiaceae family (Duan et al. 2009).

Although these bacteria attack a common host, they adopt different strategies of pathogenesis and dissemination, show different tissue specificity and cause different symptoms. X. citri invades the host leaf mesophyll tissue through natural openings such as stomata and through lesions and subsequently proliferates in the intercellular spaces. The bacterium can also survive and multiply outside the host as an epiphyte. On the other hand, $X$. fastidiosa and Candidatus Liberibacter are vectored by insects and proliferate in the vascular system of the host, where they are limited to either the phloem (Candidatus Liberibacter) or xylem (X. fastidiosa). Candidatus Liberibacter is unique amongst plant pathogenic bacteria in that it occurs within plant cells.

There is a great deal of interest in understanding the molecular mechanisms of pathogenesis of these three major pathogens of citrus plants as a route to identification of new strategies for disease management. The economical and social impact of these diseases to the citrus industry encouraged the sequencing of the complete genome of all three pathogens (Simpson et al. 2000; da Silva et al. 2002; Duan et al. 2009). Indeed, $X$. fastidiosa was the first plant pathogenic bacterium to be sequenced (Simpson et al. 2000). The determination of the genome sequence of $\mathrm{Ca}$. Liberibacter asiaticus presented a particular problem since conditions for the cultivation of this fastidious organism and the related Candidatus L. americanus and Candidatus L. africanus were only very recently reported (Sechler et al. 2009). The full genome sequence of $C a$. L. asiaticus was determined using a metagenomic approach on DNA extracted from a single insect vector or from the phloem of an HLB-infected tree (Duan et al. 2009; Tyler et al. 2009).

Comparative genomic studies have identified a number of genes and operons that might be relevant to the adaptation to citrus, interactions with insects and to tissue specificity. In addition to these genomic studies, work to identify virulence factors in X. citri and X. fastidiosa has been informed by investigations on other xanthomonads such as the brassica pathogen Xanthomonas campestris pv. campestris and rice pathogen Xanthomonas oryzae pv. oryzae. In this review, we present an overview of the biology of each of the pathogens, the diseases they cause and current management practices, comparative genomics of the three citrus pathogens and discuss existing knowledge of virulence mechanisms and their regulation, with an emphasis on cell-cell signalling. The roles of secretion systems, biofilm formation and attachment are also included.

\section{General features of the bacterial diseases in citrus and economic impacts}

Citrus canker

CCD is caused by five different groups of $X$. citri strains with variation in host range: three from Asia $\left(A, A^{*}\right.$ and $\mathrm{Aw})$ and two that form a phylogenetically distinct group originated in South America (B and C). The Asiatic (A) group ( $X$. citri pv. citri $\mathrm{A}$ ) has the widest host range and is widespread throughout the world. The $\mathrm{B}$ and $\mathrm{C}$ groups (X. citri pv. aurantifolii B and C) have only been found in South America and have a reduced host range compared with the A groups (Stall and Seymour 1983). New groups of $X$. citri pv. citri (Aw from Florida and $\mathrm{A}^{*}$ from Southwest Asia) were found primarily on Mexican lime (Citrus aurantifolia) and are restricted in host range and pathogenicity (Verniere et al. 1998; Sun et al. 2004).

Canker symptoms on leaves and fruit are characterised by surface-penetrating necrotic lesions surrounded by oily, water-soaked margins and yellow chlorotic rings (Brunings and Gabriel 2003) (Fig. 1a). All cultivars of citrus are susceptible to canker and the bacteria entrance occurs mainly through stomata and wounds. Differences in leaf characteristics such as rapidity of development of the cuticle and the number and structure of stomata have been implicated in the differences between susceptible (grapefruit, Mexican lime and lemon) and moderately resistant (mandarins) plants. Infected fruits have decreased commercial qualities and are rejected by most important markets (Canteros 2004).

Two different lines of defence against CCD have been employed: spray application of antibiotics and copperbased products and eradication through removal of infected as well as the surrounding trees within an appropriate radius. The more to most effective way to eliminate the disease before it becomes endemic is through the removal of affected plants, a procedure that causes significant economical losses. In São Paulo State, the main citrus production area in Brazil, it is mandatory to eliminate all plants around the focus of infection in a 
$30-\mathrm{m}$ radius if the contaminated plants are less than $0.5 \%$ of the planting block and all plants in the planted block if the index of contaminated plants is more than $0.5 \%$. In the latter case, cultivation is then prohibited in the area for the next 3 years and there is no payment for lost production to the growers. In Florida, the eradication was considered infeasible due to the wide distribution caused by the hurricane season of 2004, then the programme was interrupted in 2006. CCD has a further great impact on the economy of the citrus industry in a specific country or region due to quarantine restrictions imposed by some importer countries (the so-called non-tariff trade barriers).

\section{Citrus variegated chlorosis}

$X$ fastidiosa is the causal agent of diseases of economically important crops such as grapevine, plum almond, peach, coffee and citrus (Purcell and Hopkins 1996; Lima et al. 1998). However, each disease is caused by a different strain of $X$. fastidiosa. The symptoms produced by $X$. fastidiosa in CVC disease are characterised by water stress produced by bacterial aggregates and production of extracellular polysaccharide (EPS) causing vascular occlusion in xylem vessels (de Souza et al. 2003). The most common symptoms are smaller and mottled fruits that are maturing together with reduced leaf size exhibiting a chlorosis similar to that seen in zinc deficiency (Fig. 1b). Young leaves do not show symptoms but as they mature, small light brown gummy lesions appear which in due time become dark brown or even necrotic. X. fastidiosa is transmitted amongst plants by leafhoppers (Hemiptera, Cicadellidae) or spittlebugs (Purcell and Hopkins 1996).

\section{Huanglongbing}

HLB is the disease of citrus formerly known as citrus greening. The name, which in Mandarin means the 'yellow shoot disease', refers to the presence of yellowish twigs in infected citrus plants (Fig. 1c). HLB is more destructive and devastating than previous citrus disease epidemics because of the lack of efficient control coupled with the insectvectored mechanism of dissemination; great losses have been caused in citrus industries throughout the world (Hsiang 1956; Bové 2006). The disease was first detected in 1919 in China, subsequently reported in South Africa also in the early twentieth century and later spread to several countries in both continents (Zhao 1981; Bové 2006). HLB is characterised by the presence of yellow shoots, blotchy mottle on the leaves and fruits that are small and lop-sided, with inverted colouring. Three $\alpha$-Proteobacteria species are associated with this citrus disease: $\mathrm{Ca}$. Liberibacter asiaticus in Asia, Ca. L. africanus in Africa (Jagoueix et al. 1994) and Ca. L. americanus in Brazil, South America (Teixeira 2005). Although Ca. L. asiaticus does not always produce disease, it can invade the most rutaceous species and some solanaceous (Halbert and Manjunath 2004). Psyllid insects mediate transmission of the pathogen amongst plants. $C a$. L. asiaticus and $C a$. L. americanus are transmitted amongst citrus trees in Asia and America by Diaphorina citri whereas Ca. L. africanus is
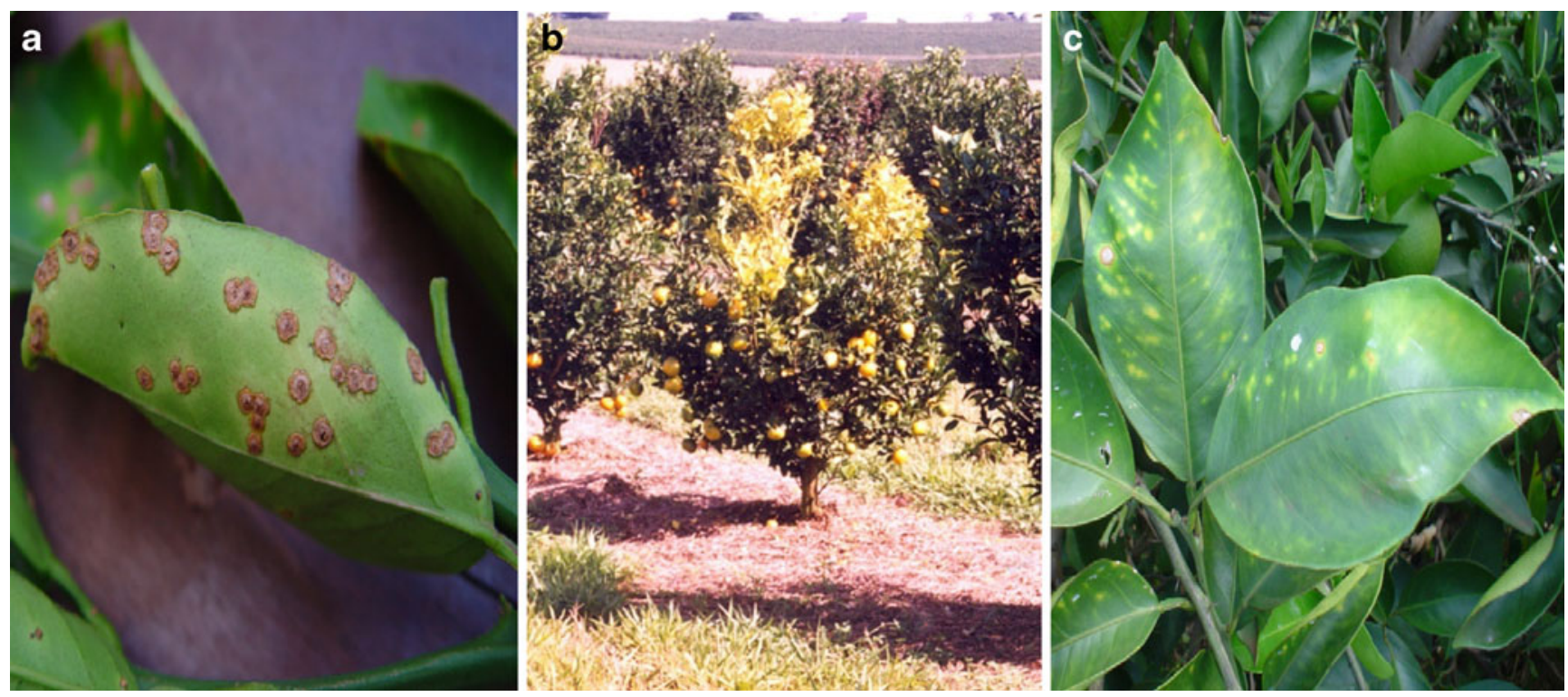

Fig. 1 Bacterial symptoms on citrus plants: lesions caused by citrus canker on citrus leaves (a), 'yellow shoot' symptoms of huanglongbing on citrus tree (b) and citrus variegated chlorosis $(\mathbf{c})$ 
transmitted in Africa by Trioza erytreae (McClean and Oberholzer 1965; Capoor et al. 1967; Bové 2006).

The unculturable characteristic of Candidatus Liberibacter has represented a major obstacle towards the advancement in the knowledge of HLB disease over the past century. In spite of this limitation, the entire genome sequence of ' $\mathrm{Ca}$. Liberibacter asiaticus' has been obtained by pyrosequencing technologies on DNA extracted from a single ' $C a$. L. asiaticus'-infected Asian citrus psyllid (D. citri) (Duan et al. 2009) and from phloem tissue of citrus trees infected with HLB (Tyler et al. 2009). This is the first genome sequence of an $\alpha$-Proteobacterium that acts as both an intracellular plant pathogen and an insect symbiont. A very recent report describes the cultivation of Candidatus Liberibacter in vitro in a medium used previously for spiroplasmas or $X$. fastidiosa growth supplemented with citrus vein extract (Sechler et al. 2009). This represents an important first step towards functional genomic analysis of virulence in this pathogen.

\section{Comparative genomic analysis}

The general features of the genomes of the three major citrus bacterial pathogens are summarised in Table 1. The genome sequence of $X$. citri comprises 5,175,554 bp of chromosomal sequence and two plasmid sequences $(64,920$ and $33,699 \mathrm{bp})$ whereas the other two bacteria show much more reduced genome content. X. fastidiosa, which is related to $X$. citri, comprises $2,679,305$ bp of chromosomal sequence and two plasmids $(51,158$ and $1,285 \mathrm{bp}$ ) whereas $C a$. Liberibacter asiaticus has only one chromosome $(1,227,204 \mathrm{bp}$ in length) with no plasmids (Table 1). The reduced genome size of $X$. fastidiosa and $\mathrm{Ca}$. Liberibacter asiaticus may reflect a lifestyle in which the bacteria are always intimately associated with either a plant or insect host. In contrast, the larger genome size of $X$. citri may reflect the added capability of this organism to grow outside the plant either as an epiphyte on plant leaf surfaces or in the soil in association with dead plant parts. It is important to note that $\mathrm{Ca}$. Liberibacter asiaticus contains genetic features distinctive due to its obligate intracellular characteristic (Moran 2002), such as having a small genome size, a low GC content (36.5\%) and a significant genome reduction compared to other members of the Rhizobiaceae family. The information revealed by this newly completed genome may make it possible to identify those conditions necessary for its growth in culture as well as aid in our understanding of how this pathogen becomes established in both its vector and plant hosts. This genome knowledge may also provide information relevant to two other genomes of HLB bacteria, $\mathrm{Ca}$. Liberibacter americanus and $\mathrm{Ca}$. Liberibacter africanus.

To compare the content of shared genes, a BLAST search amongst all predicted ORFs in the $X$. citri, X. fastidiosa and $C a$. Liberibacter asiaticus genomes was performed. Reciprocal best matches were counted by a BLAST result with an expectation value $E$ of $<1 \mathrm{e}-10$ each. A total of 96 protein clusters were conserved in all three genomes
Table 1 General genome features of the three major citrus bacterial pathogens Xanthomonas citri pv. citri, Xylella fastidiosa and 'Candidatus Liberibacter asiaticus'

\begin{tabular}{lccl}
\hline & $X$. citri & X. fastidiosa & Ca. Liberibacter asiaticus \\
\hline Chromosome & & & \\
Length (bp) & $5,175,554$ & $2,679,305$ & $1,227,204$ \\
G+C content (\%) & 64.7 & 52.7 & 36.5 \\
Protein-coding genes & 4,313 & 2,782 & 1,136 \\
Hypothetical proteins & 331 & 1,083 & 362 \\
tRNA & 54 & 49 & 44 \\
Plasmids & 2 & 2 & 0 \\
Plasmid 1 & & & \\
Length (bp) & 64,920 & 51,158 & - \\
G+C content (\%) & 61.4 & 49.6 & - \\
Protein-coding genes & 73 & 64 & - \\
Hypothetical proteins & 27 & 24 & - \\
Plasmid 2 & & & - \\
Length (bp) & 33,699 & 1,285 & - \\
G+C content (\%) & 61.9 & 55.6 & - \\
Protein-coding genes & 14 & 2 & - \\
Hypothetical proteins & 42 & 1 & \\
\hline
\end{tabular}


(i.e. each cluster has at least one gene from each of the three species); the majority of these play a role in the housekeeping pathways of the cell. On the other hand, a total of 2,964 clusters of $X$. citri, 1,607 from $X$. fastidiosa and 654 from $\mathrm{Ca}$. Liberibacter asiaticus were unique to those organisms (Fig. 2).

Genomic insights into virulence-related functions: secretion systems

Bacterial secretion systems are important for the interaction of pathogens with the host. They serve to deliver virulence determinants to the bacterial environment or within the host cell, can act in secretion of adhesins involved in attachment and biofilm formation and are involved in defence against antimicrobial agents of host origin.

Type I secretion systems are involved in the secretion of toxins such as haemolysins and in the import and efflux of a variety of compounds including drugs. All three pathogens appear to have such systems. Type II secretion systems (T2SS) of plant pathogenic bacteria secrete a number of possible virulence determinants into the bacterial environment, including enzymes with plant cell walldegrading activity. $X$. citri has two different T2SS (encoded by the xps and xcs gene clusters), a large number of cell wall-degrading enzymes and sugar transporters, which may act in taking up the products of enzymatic degradation of plant polysaccharides. In contrast, X. fastidiosa has only

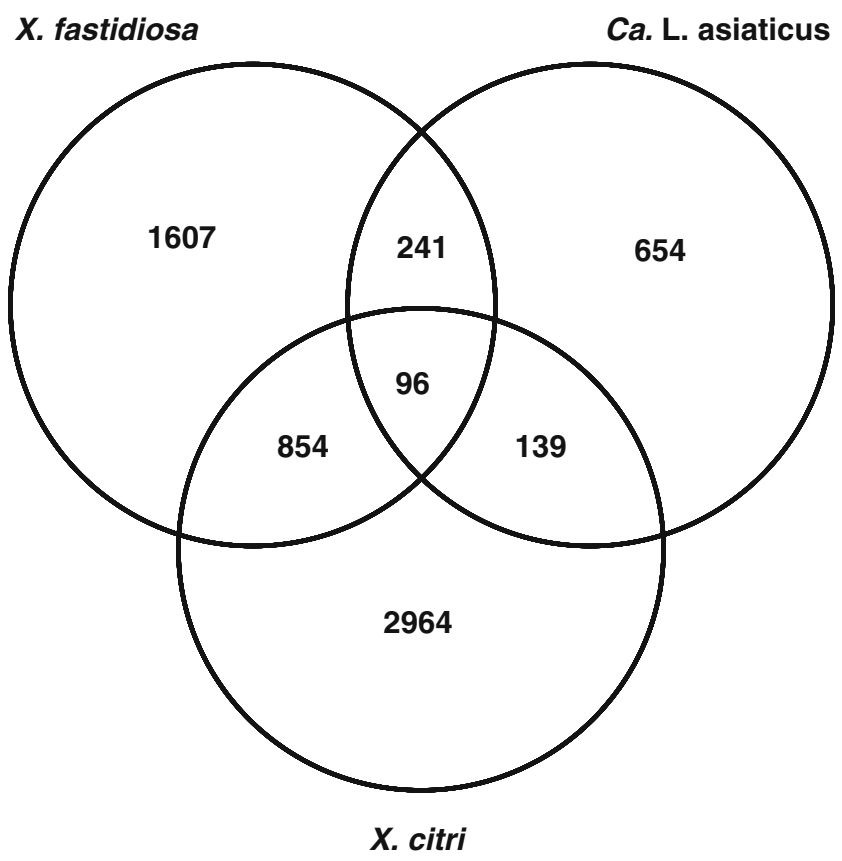

Fig. 2 Venn diagram representing the number of clusters of related protein families. Comparative analysis of the X. citri (Xac), Xylella fastidiosa $(X f)$ and $\mathrm{Ca}$. Liberibacter asiaticus (CLas) genomes, performed by using protein clustering algorithms one T2SS, (the Xps system) and Ca. Liberibacter asiaticus has no T2SS. The $X$. fastidiosa type II secretion system is probably involved in the export of cell wall degrading enzymes, including endoglucanase, polygalacturonase and perhaps several proteases. One function of these enzymes in $X$. fastidiosa pathogenesis is to degrade the pit membranes, allowing bacteria to move into previously uncolonised xylem vessels (Roper et al. 2007; Perez-Donoso et al. 2010). Other roles may be to mobilise cell walls for nutritional purposes or to overcome plant defences. Unlike $X$. citri and X. fastidiosa, Ca. L. asiaticus lacks genes for these extracellular degradative enzymes.

Type III secretion systems (T3SS) are very conserved amongst plant and animal pathogenic bacteria and act to deliver effector proteins from the bacterial cytoplasm into the host cell. These effectors can act as virulence factors, interfering with a variety of host functions to promote disease, although in some plants, specific effectors may be recognised to trigger defence-related responses. As many effectors were originally described through this latter function, they were termed avirulence determinants. The T3SS machinery is present in X. citri but absent in both $X$. fastidiosa and $\mathrm{Ca}$. Liberibacter asiaticus. Of the effector genes in $X$. citri, pthA, a member of avrBS3/pthA genes family, plays the most important role in pathogenicity and is present in all Xanthomonas that causes canker in citrus, often in multiple copies (Swarup et al. 1992; Cubero and Graham 2002). AvrBs3/PthA family proteins contain particular structural features with 15 to 30 repeats of 34 amino acids in their central portion, a leucine zipper-like motif, nuclear localisation signals and an acid transcriptional activation domain in the C terminus (Zhu et al. 1998; Lahaye and Bonas 2001). The exact number and arrangement of their repeat units differ and contribute to function and specificity during the elicitation of resistance and virulence on the respective host species. The repeat region mediates direct binding to DNA (Kay et al. 2007) and the binding specificity is based on a two-amino acid motif per repeat (Boch et al. 2009). This binding allows effectors of the AvrBs3 family to mimic plant transcriptional activators and manipulate the plant transcriptome (Kay and Bonas 2009).

Recent screening of a transposon-based mutant library in Rangpur lime (Citrus limonia) plantlets identified two genes associated with the T3SS, $h r p B 4$ and $h r p X$ having a role in the production of canker symptoms (Laia et al. 2009). HrpB4 is not secreted and may form part of the secretion machinery, whereas $\mathrm{HrpX}$ is a regulator of the expression of genes in the hrp regulon, which encode structural components of the secretion apparatus as well as some of the secreted effectors (Laia et al. 2009).

The type IV secretion system (T4SS) is also involved in transporting macromolecules from the bacterial cytoplasm 
into the host cell cytoplasm. The best-studied T4SS is the vir-encoded system of Agrobacterium, which is involved in the transfer of the T-DNA. X. citri and X. fastidiosa have gene clusters similar to the T4SS of Bordetella pertussis which is involved in secretion of pertussis toxin (Van Sluys et al. 2002). By analogy, the T4SS systems in the citrus pathogens may also play a role in virulence. $\mathrm{Ca}$. L. asiaticus lacks both type III and type IV secretion systems, which is consistent with its intracellular nature.

$X$. fastidiosa and X. citri contain genes for surfaceassociated adhesins that appear to be type $\mathrm{V}$ secretion system autotransporters. These adhesins are very large proteins (over 3,000 amino acids) that are thought to have a role not only in adhesion to biotic surfaces but also in biofilm formation. In $X$. citri, the gene encoding the transporter protein $\mathrm{XacFhaC}$ is closely linked to a gene encoding a filamentous hemagglutinin-like protein named XacFhaB (Gottig et al. 2009). Mutational analyses indicated that $\mathrm{XacFhaB}$ is involved in virulence and influences leaf surface attachment and biofilm formation. X. fastidiosa has several large proteins with amino acid sequence that are similar to $\mathrm{XacFhaB}$, although similarity is restricted to domains located at the $\mathrm{N}$ and $\mathrm{C}$ termini. No proteins with related domains are seen in $\mathrm{Ca}$. L. asiaticus.

As outlined above, genome sequence comparisons can identify groups of species-specific genes that may be associated with the particular lifestyle, mode of transmission or symptoms produced by each phytopathogen. Such comparisons can guide functional genomic analyses and prioritise genes for study. However, it is evident that, in addition to differences in gene complement, diverse regulatory actions of components that are conserved between bacteria may underpin different bacterial lifestyles. One example is the divergent role of the Rpf/DSF cell-cell signalling system in $X$. citri and $X$. fastidiosa, which we discuss in the following sections.

\section{Conserved cell-cell signalling systems have different regulatory actions in $X$. citri and $X$. fastidiosa}

Bacterial quorum sensing regulates gene expression in a cell-density-dependent manner through a synthesis of a variety of small signalling molecules (Whitehead et al. 2001; Bassler 2002). In X. citri and X. fastidiosa, as in other bacteria, cell-to-cell signalling plays an important role in colonisation, pathogenesis and biofilm formation (Siciliano et al. 2006; Chatterjee et al. 2008b). Both bacteria have a cell-to-cell signalling system mediated by a diffusible signal molecule called DSF. Genes within the rpf cluster (for regulation of pathogenicity factors) encode the components of the DSF signalling system (Barber et al. 1997; Newman et al. 2004; Chatterjee et al. 2008b). RpfF is responsible for the synthesis of DSF whereas RpfC and RpfG comprise a two-component system implicated in DSF perception and signal transduction (Tang et al. 1991; Dow and Daniels 1994; Barber et al. 1997; Slater et al. 2000; Chatterjee et al. 2008b). RpfC is a complex sensor kinase with an $\mathrm{N}$-terminal membrane-associated input domain, histidine kinase domain, CheY-like receiver domain and a $\mathrm{C}$-terminal $\mathrm{HPt}$ domain. RpfG is a response regulator with a CheY-like receiver domain attached to an HD-GYP domain that acts in degradation of the second messenger cyclic di-GMP (Barber et al. 1997; Ryan et al. 2006). DSF from $X$. campestris has been characterised as the unsaturated fatty acid cis-11-methyl-dodecenoic acid (Wang et al. 2004). An ethyl acetate extract from $X$. citri supernatant is active in phenotypic complementation of an $X$. campestris rpfF strain, suggesting a similar structure for DSF in $X$. citri. The $X$. fastidiosa DSF molecule was tentatively identified as 12-methyl-tetradecanoic acid (Colnaghi Simionato et al. 2007).

The current model for DSF signal transduction in Xanthomonas is that perception of the signal by the membrane-associated domain of RpfC triggers autophosphorylation of the sensor, followed by phosphorelay and phosphotransfer from the HPt domain to the receiver domain of the RpfG regulator. Phosphorylation of the receiver domain of RpfG alters the activity of the protein in cyclic di-GMP degradation, an activity associated with the HD-GYP domain. Perception of DSF thus leads to a reduction in cellular levels of cyclic di-GMP, with consequences for the regulation of diverse cellular processes (Fig. 3).

Although the Rpf proteins from the different xanthomonads have a high degree of amino acid sequence similarity, the regulatory action of these components is diversified between Xanthomonas spp. and X. fastidiosa. In $X$. campestris and $X$. citri, rpfF mutants, which are DSF deficient, have lower expression of virulence-associated functions such as EPS and extracellular enzymes and reduced virulence to plants (Barber et al. 1997; Siciliano et al. 2006). In contrast, in $X$. fastidiosa, an $r p f F$ mutant has enhanced expression of genes encoding the production of the extracellular enzymes such as polygalacturonase ( $p g l A)$ and type IV pili, while those encoding a variety of adhesins are reduced (Chatterjee et al. 2008a). Accordingly, DSF-deficient mutants of $X$. fastidiosa showed enhanced virulence but a reduced capacity to colonise the insect vector (Newman et al. 2004; Chatterjee et al. 2008a).

In $X$. citri and $X$. campestris, $r p f C$ mutants have similar phenotypes to $r p f F$ mutants. Intriguingly, in $X$. fastidiosa, mutation of $r p f C$ has an opposite effect on expression of specific traits to mutation of $r p f F$. The $r p f C$ mutant shows reduced virulence but enhanced attachment and biofilm 


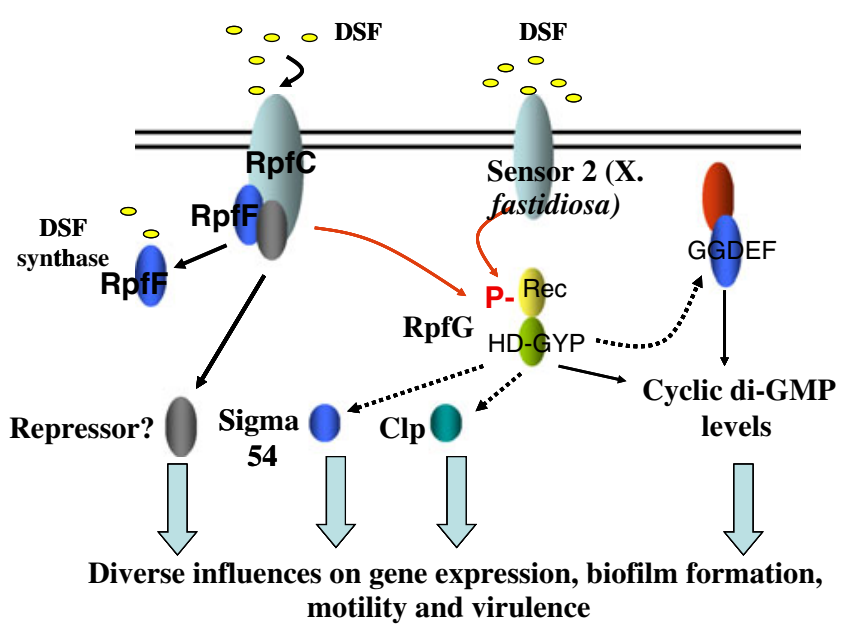

Fig. 3 Signal transduction by the Rpf/DSF signalling system in xanthomonads. RpfF is the enzyme responsible for DSF synthesis whereas RpfC is a sensor kinase responsible for DSF perception. $\mathrm{RpfC}$ sequesters RpfF and perhaps other regulators that may be released after conformational changes that occur upon DSF binding, which is believed to be to the RpfC sensory input domain. The consequences are further induction of synthesis of DSF and alteration in expression of particular subsets of genes. Binding of DSF also triggers autophosphorylation of RpfC and phosphorelay to RpfG (red arrow), thereby activating cyclic di-GMP degradation by the HD-GYP domain. RpfG may also physically interact with GGDEF domain (diguanylate cyclase) proteins to influence cyclic di-GMP concentrations and with other regulators, modulating their activity in transcription (dotted lines). In Xylella fastidiosa, a second sensor may phosphorylate RpfG in response to DSF. Although shown as a membrane-bound protein, this sensor may equally be located in the cytoplasm. In $X$. campestris, RpfG influences expression of Clp by an unknown mechanism, leading to activation of a downstream signalling cascade involving other transcriptional regulators. It is not known whether this occurs in Xylella fastidiosa

formation, which is correlated with an elevated expression of genes encoding the adhesins HxfA, HxfB and FimA. The $r p f C$ mutant can colonise the insect vector (unlike the $r p f F$ mutant), but it is not transmitted to the host plant. In contrast to these divergent effects on expression of adhesin genes, mutation of $r p f F$ and $r p f C$ has similar effects on the expression of genes encoding other virulence determinants; expression of tolC, which encodes a protein involved in type I secretion and $p g l A$ is increased in both $r p f F$ and $r p f C$ mutants (Chatterjee et al. 2008b).

The occurrence of further regulatory complexity is evident from studies of an rpfCrpfF double mutant of $X$. fastidiosa. This strain, which has similar virulence to that of the wild type (and greater virulence than that of the $r p f C$ mutant), shows less expression of tolC and pglA than either of the single mutants. Chatterjee et al. (2008b) have proposed that the decreased expression of the tolC and $p g l A$ in the rpfCrpfF double mutant is due to the action of a repressor which is normally sequestered by protein-protein interaction with either RpfC or RpfF. Since DSF has a positive effect on regulation of adhesin genes even in an $r p f C$ mutant, Chatterjee and colleagues further propose the existence of two distinct pathways for DSF perception in $X$. fastidiosa (Chatterjee et al. 2008bl; Dow 2008). In the first pathway, in which RpfC acts as the sensor, DSF negatively regulates expression of $r p f F$, tolC and $p g l A$ independently of RpfG and activates genes involved in biofilm formation through RpfG. In the second pathway, a separate (perhaps intracellular) sensor acts in conjunction with RpfG to positively regulate expression of genes linked to biofilm formation (Fig. 3).

RpfC also acts in negative regulation of DSF synthesis. In Xanthomonas spp. and in X. fastidiosa, mutation of $r p f C$ gene results in elevated production of DSF (Chatterjee et al. 2008b). In $X$. fastidiosa, the expression of $r p f F$ is increased in the $r p f C$ mutant (Chatterjee et al. 2008b) whereas in the $r p f C$ mutant of $X$. campestris, the expression of $r p f F$ is not changed (Slater et al. 2000). The negative effects of RpfC on DSF synthesis does not require the phosphorelay and may be exerted by sequestration of RpfF by binding to the CheY-like receiver domain of $\mathrm{RpfC}$ ( $\mathrm{He}$ and Zhang 2008). RpfC is thus proposed to have dual signalling functions involving either phosphorelay (for example in the regulation of extracellular enzyme synthesis in X. citri) or protein-protein interaction (such as in regulation of DSF synthesis in $X$. citri and $X$. fastidiosa or in modulation of the action of the putative repressor in $X$. fastidiosa).

\section{Diversification in cyclic di-GMP signalling in $X$. citri and $X$. fastidiosa}

As outlined above, DSF signal transduction is linked to alteration in the levels of the second messenger cyclic di-GMP through the HD-GYP domain protein RpfG (Fouhy et al. 2006). Two other protein domains, GGDEF and EAL, are also involved in cyclic di-GMP synthesis or degradation; the GGDEF domain is a cyclic di-GMP synthase whereas EAL and HD-GYP are phosphodiesterases, implicated in cyclic di-GMP degradation (D'Argenio and Miller 2004; Dow et al. 2006; Ryan et al. 2006). Many of the proteins with these domains have additional sensory domains, suggesting that their activities are responsive to environmental cues. The complement of proteins with a role in cyclic di-GMP turnover is very different in $X$. citri and $X$. fastidiosa; $X$. citri has 34 proteins with GGDEF, EAL and HD-GYP domains whereas $X$. fastidiosa has 5 . Only one of these proteins (RpfG) is common to both bacteria. Cyclic di-GMP exerts an action on multiple regulatory targets in bacteria and it is conceivable that these targets are different in $X$. citri and $X$. fastidiosa. This may in part explain differences in the role of DSF signalling in the two bacteria. Furthermore, yeast two-hybrid analysis 
indicates that the HD-GYP domain of RpfG from $X$. citri physically interacts with certain GGDEF domain proteins and also with other regulators such as sigma 54 and $\mathrm{NtrBC}$ (Andrade et al. 2006). Although the significance of these interactions to regulation in response to DSF signal transduction is currently unclear, differences in the interactions in $X$. citri and X. fastidiosa could also contribute to the different regulatory outputs from a signalling system whose most upstream components are conserved.

\section{Biofilm development and virulence}

$X$. citri and $X$. fastidiosa can develop biofilms, structures in which the bacteria are held together in an extracellular matrix and usually attached to a surface. Biofilm formation is an important factor for pathogenicity (de Souza et al. 2004; Rigano et al. 2007). In X. fastidiosa, the mature biofilm morphology in cultures grown on glass cover slips was analysed by light transmission microscopy from 3 to 30 days of growth (de Souza et al. 2004). During the first 5 days, the bacteria became adhered to the glass surface. This phase was followed by formation of small compact aggregates at 15 days. Later, at 30 days, a complete mature biofilm was observed (de Souza et al. 2004). Comparative gene expression between bacteria from this mature biofilm or those grown planktonically for 30 days was examined using DNA microarrays harbouring about 2,200 ORFs from the genome of $X$. fastidiosa strain 9a5c (de Souza et al. 2004). Genes relating to adhesion and adaptation were upregulated in bacteria in the biofilm. These genes included pilA, fimA and pilC, which are involved in the synthesis of pili that have an established role in initial attachment and biofilm formation. Other upregulated genes included those with roles in resistance to antimicrobial agents, the general secretion pathway, synthesis of osmoregulated periplasmic glucans and structural genes for cellulase and proteases (de Souza et al. 2004). In contrast, genes involved in exopolysaccharide (EPS) biosynthesis or in cell-cell signalling ( $r p f$ genes) were not differentially expressed between biofilm and planktonic cells. This is perhaps surprising, since the $r p f / D S F$ system has a role in controlling adhesion in $X$. fastidiosa (Chatterjee et al. 2008b) and EPS is necessary for biofilm formation in Xanthomonas spp. (Dow et al. 2000, 2003; Rigano et al. 2007; Torres et al. 2007). As we have seen, the Rpf/DSF system is linked to cyclic di-GMP as a second messenger, and in many bacteria, elevated levels of cyclic di-GMP promote biofilm formation. However, this nucleotide can exert a regulatory influence and act at the posttranslational level, for example, in allosteric activation of polysaccharide synthesis, so that transcriptional profiling alone may not explain all phenotypic variations between biofilm and planktonic cells.

Studies of biofilm in $X$. citri have been performed on static cultures grown in minimal medium containing glucose in chambered covered slides. Biofilms were observed by confocal laser scanning microscopy of bacteria expressing fluorescent proteins (Rigano et al. 2007). After 4 to 5 days under these growth conditions, the wild-type $X$. citri forms a structured biofilm in which the bacteria contact the glass surface through one cell pole and are predominantly attached to each other through lateral interactions to form compact three-dimensional structures. Neither the $r p f F$ mutant, which does not produce DSF, nor the $\operatorname{rpfC}$ mutant, which is a DSF over-producer produces a biofilm with this architecture. Mutants that cannot make EPS are also defective in biofilm formation (Rigano et al. 2007).

The role of bacterial attachment and biofilm formation on colonisation and during canker development was studied in lemon leaves using wild-type and EPSdeficient (biofilm-defective) bacteria expressing fluorescent proteins (Rigano et al. 2007). The findings indicated that the formation of biofilms is important in the epiphytic survival of $X$. citri prior to development of canker disease.

\section{Concluding remarks}

Although comparative genomics has revealed differences in the gene complement amongst all three major bacterial pathogens of citrus, it is still unclear how these differences are related to the different lifestyles of the organisms, tissue specificity, adaptation to different environments and interactions with insect vectors. Nevertheless, knowledge of the genome sequences has been extremely useful in identifying candidate genes with a role in virulence in $X$. fastidiosa and $X$. citri and in developing improved detection methods for all three organisms. The determination of the genome sequence of $\mathrm{Ca}$. Liberibacter asiaticus and the recent report of cultivation of the organism offer the prospect that systems for genetic manipulation can be developed to allow functional genomic analysis. The information from such studies should suggest new strategies for disease control. This may take the form of inhibition of key virulence activities. For example, interference with DSF mediated cell-cell signalling offers a potential route to restrict $X$. citri or $X$. fastidiosa infection. Both signal degradation and signal overproduction may have the desired outcome on disease progression, which could be achieved by the use of epiphytic or xylem-colonising bacteria that degrade the signal, or conversely by genetic manipulation of these 
organisms or of the host plant to express RpfF and hence elevate DSF levels. Although the use of chemicals to target the biochemical activity of key virulence factors has been effective in the therapy of human bacterial diseases, satisfactory chemical control of bacterial diseases of plants has not been achieved historically, except for those bacteria that need insect vectors where insecticides may disrupt the disease cycle. In general, the most effective management measure of plant disease, apart from use of good agronomic practices, is the deployment of genetic resistance to pathogens. The identification of new bacterial virulence factors and mechanisms should permit the development of assays to reveal natural genetic variation in plants or to guide the manipulation of targets in the laboratory.

Acknowledgements MRM, APC and AAV are Career Investigators of Consejo Nacional de Investigaciones Científicas y Técnicas (CONICET), Argentina and are supported by Agencia Nacional de Promoción Científica y Tecnológica. JMD is supported by a Principal Investigator Award 07/IN.1/B955 from the Science Foundation of Ireland. AMdoA received a fellowship from $\mathrm{CNPq}$. We thank Luciano Kishi for his help with the Venn diagram.

\section{References}

Andrade MO, Alegria MC, Guzzo CR, Docena C, Rosa MC, Ramos CH, Farah CS (2006) The HD-GYP domain of RpfG mediates a direct linkage between the Rpf quorum-sensing pathway and a subset of diguanylate cyclase proteins in the phytopathogen Xanthomonas axonopodis pv citri. Mol Microbiol 62:537-551

Barber CE, Tang JL, Feng JX, Pan MQ, Wilson TJ, Slater H, Dow JM, Williams P, Daniels MJ (1997) A novel regulatory system required for pathogenicity of Xanthomonas campestris is mediated by a small diffusible signal molecule. Mol Microbiol 24:555-566

Bassler BL (2002) Small talk. Cell-to-cell communication in bacteria. Cell 109:421-424

Boch J, Scholze H, Schornack S, Landgraf A, Hahn S, Kay S, Lahaye T, Nickstadt A, Bonas U (2009) Breaking the code of DNA binding specificity of TAL-type III effectors. Science 326:1509-1512

Bove JM (2006) Huanglongbing: a destructive, newly-emerging, century-old disease of citrus. J Plant Pathol 88:7-37

Bové JM (2006) Huanglongbing: a destructive, newly-emerging, century-old disease of citrus. J Plant Pathol 88:7-37

Brunings AM, Gabriel DW (2003) Xanthomonas citri: breaking the surface. Mol Plant Pathol 4:141-157

Callaway E (2008) Bioterror: the green menace. Nature 452:148-150

Canteros BI (2004) Management of citrus canker in Argentina. A review. In: Ait-Oubahou A, El-Otmani M (eds) Proceedings of the Tenth International Society of Citriculture Congress, Agadir, Morocco, 15-20 February 2004, vol 1. International Society of Citriculture, Agadir, pp 448-451

Capoor SP, Rao DG, Viswanat SM (1967) Diaphorina citri Kuway., a vector of greening disease of citrus in India. Indian J Agric Sci $37: 572-576$

Chatterjee S, Newman KL, Lindow SE (2008a) Cell-to-cell signaling in Xylella fastidiosa suppresses movement and xylem vessel colonization in grape. Mol Plant Microb Interact 21:1309-1315
Chatterjee S, Wistrom C, Lindow SE (2008b) A cell-cell signaling sensor is required for virulence and insect transmission of Xylella fastidiosa. Proc Natl Acad Sci U S A 105:2670-2675

Colnaghi Simionato AV, da Silva DS, Lambais MR, Carrilho E (2007) Characterization of a putative Xylella fastidiosa diffusible signal factor by HRGC-EI-MS. J Mass Spectrom 42:1375-1381

Cubero J, Graham JH (2002) Genetic relationship among worldwide strains of Xanthomonas causing canker in citrus species and design of new primers for their identification by PCR. Appl Environ Microbiol 68:1257-1264

D'Argenio DA, Miller SI (2004) Cyclic di-GMP as a bacterial second messenger. Microbiology 150:2497-2502

da Silva AC, Ferro JA, Reinach FC, Farah CS, Furlan LR, Quaggio RB, Monteiro-Vitorello CB, Van Sluys MA, Almeida NF, Alves LM, do Amaral AM, Bertolini MC, Camargo LE, Camarotte G, Cannavan F, Cardozo J, Chambergo F, Ciapina LP, Cicarelli RM, Coutinho LL, Cursino-Santos JR, El-Dorry H, Faria JB, Ferreira AJ, Ferreira RC, Ferro MI, Formighieri EF, Franco MC, Greggio CC, Gruber A, Katsuyama AM, Kishi LT, Leite RP, Lemos EG, Lemos MV, Locali EC, Machado MA, Madeira AM, MartinezRossi NM, Martins EC, Meidanis J, Menck CF, Miyaki CY, Moon DH, Moreira LM, Novo MT, Okura VK, Oliveira MC, Oliveira VR, Pereira HA, Rossi A, Sena JA, Silva C, de Souza RF, Spinola LA, Takita MA, Tamura RE, Teixeira EC, Tezza RI, Trindade dos Santos M, Truffi D, Tsai SM, White FF, Setubal JC, Kitajima JP (2002) Comparison of the genomes of two Xanthomonas pathogens with differing host specificities. Nature 417:459-463

de Souza AA, Takita MA, Coletta-Filho HD, Caldana C, Goldman GH, Yanai GM, Muto NH, de Oliveira RC, Nunes LR, Machado MA (2003) Analysis of gene expression in two growth states of Xylella fastidiosa and its relationship with pathogenicity. Mol Plant Microb Interact 16:867-875

de Souza AA, Takita MA, Coletta-Filho HD, Caldana C, Yanai GM, Muto NH, de Oliveira RC, Nunes LR, Machado MA (2004) Gene expression profile of the plant pathogen Xylella fastidiosa during biofilm formation in vitro. FEMS Microbiol Lett 237:341-353

Doddapaneni H, Liao H, Lin H, Bai X, Zhao X, Civerolo EL, Irey M, Coletta-Filho H, Pietersen G (2008) Comparative phylogenomics and multi-gene cluster analyses of the citrus Huanglongbing (HLB)-associated bacterium Candidatus Liberibacter. BMC Res Notes 1:72

Dow JM, Crossman L, Findlay K, He YQ, Feng JX, Tang JL (2003) Biofilm dispersal in Xanthomonas campestris is controlled by cell-cell signaling and is required for full virulence to plants. Proc Natl Acad Sci U S A 100:10995-11000

Dow JM, Daniels MJ (1994) Pathogenicity determinants and global regulation of pathogenicity of Xanthomonas campestris pv. campestris. Curr Top Microbiol Immunol 192:29-41

Dow JM, Feng JX, Barber CE, Tang JL, Daniels MJ (2000) Novel genes involved in the regulation of pathogenicity factor production within the rpf gene cluster of Xanthomonas campestris. Microbiology 146(Pt 4):885-891

Dow JM, Fouhy Y, Lucey JF, Ryan RP (2006) The HD-GYP domain, cyclic di-GMP signaling, and bacterial virulence to plants. Mol Plant Microb Interact 19:1378-1384

Dow M (2008) Diversification of the function of cell-to-cell signaling in regulation of virulence within plant pathogenic xanthomonads. Sci Signal 1:pe23

Duan Y, Zhou L, Hall DG, Li W, Doddapaneni H, Lin H, Liu L, Vahling CM, Gabriel DW, Williams KP, Dickerman A, Sun Y, Gottwald T (2009) Complete genome sequence of citrus huanglongbing bacterium, 'Candidatus Liberibacter asiaticus ' obtained through metagenomics. Mol Plant Microb Interact 22:1011-1020 
Fouhy Y, Lucey JF, Ryan RP, Dow JM (2006) Cell-cell signaling, cyclic di-GMP turnover and regulation of virulence in Xanthomonas campestris. Res Microbiol 157:899-904

Gottig N, Garavaglia BS, Garofalo CG, Orellano EG, Ottado J (2009) A filamentous hemagglutinin-like protein of Xanthomonas axonopodis pv. citri, the phytopathogen responsible for citrus canker, is involved in bacterial virulence. PLoS ONE 4:e4358

Halbert SE, Manjunath KL (2004) Asian citrus psyllids (Sternorrhyncha: Psyllidae) and greening disease of citrus: a literature review and ssessment of risk in Florida. Fla Entomol 87:330-353

He YW, Zhang LH (2008) Quorum sensing and virulence regulation in Xanthomonas campestris. FEMS Microbiol Rev 32:842-857

Hsiang LK (1956) Yellow shoot of citrus. Symptomatology. Investigations in the cause of huanglongbing. Natural transmission and spread. General conclusions. Acta Phytopathologica Sinica 2:1-42

Jagoueix S, Bove JM, Garnier M (1994) The phloem-limited bacterium of greening disease of citrus is a member of the alpha subdivision of the Proteobacteria. Int J Syst Bacteriol 44:379386

Kay S, Bonas U (2009) How Xanthomonas type III effectors manipulate the host plant. Curr Opin Microbiol 12:37-43

Kay S, Hahn S, Marois E, Hause G, Bonas U (2007) A bacterial effector acts as a plant transcription factor and induces a cell size regulator. Science 318:648-651

Lahaye T, Bonas U (2001) Molecular secrets of bacterial type III effector proteins. Trends Plant Sci 6:479-485

Laia ML, Moreira LM, Dezajacomo J, Brigati JB, Ferreira CB, Ferro MI, Silva AC, Ferro JA, Oliveira JC (2009) New genes of Xanthomonas citri subsp. citri involved in pathogenesis and adaptation revealed by a transposon-based mutant library. BMC Microbiol 9:12

Lima JEO, Miranda VS, Hartung JS, Brlansky RH, Coutinho A, Roberto SR, Carlos EF (1998) Coffee leaf scorch bacterium: axenic culture, pathogenicity, and comparison with Xylella fastidiosa of citrus. Plant Dis 82:94-97

McClean APD, Oberholzer PCJ (1965) Citrus psylla, a vector of the greening disease of sweet orange. S Afr J Agric Sci 8:297-298

Moran NA (2002) Microbial minimalism: genome reduction in bacterial pathogens. Cell 108:583-586

Newman KL, Almeida RP, Purcell AH, Lindow SE (2004) Cell-cell signaling controls Xylella fastidiosa interactions with both insects and plants. Proc Natl Acad Sci U S A 101:1737-1742

Perez-Donoso AG, Sun Q, Roper MC, Greve LC, Kirkpatrick B, Labavitch JM (2010) Cell wall-degrading enzymes enlarge the pore size of intervessel pit membranes in healthy and Xylella fastidiosa-infected grapevines. Plant Physiol 152:1748-1759

Purcell AH, Hopkins DL (1996) Fastidious xylem-limited bacterial plant pathogens. Annu Rev Phytopathol 34:131-151

Rigano LA, Siciliano F, Enrique R, Sendin L, Filippone P, Torres PS, Questa J, Dow JM, Castagnaro AP, Vojnov AA, Marano MR (2007) Biofilm formation, epiphytic fitness, and canker development in Xanthomonas axonopodis pv. citri. Mol Plant Microb Interact 20:1222-1230

Roper MC, Greve LC, Warren JG, Labavitch JM, Kirkpatrick BC (2007) Xylella fastidiosa requires polygalacturonase for colonization and pathogenicity in Vitis vinifera grapevines. Mol Plant Microb Interact 20:411-419

Ryan RP, Fouhy Y, Lucey JF, Crossman LC, Spiro S, He YW, Zhang LH, Heeb S, Camara M, Williams P, Dow JM (2006) Cell-cell signaling in Xanthomonas campestris involves an HD-GYP domain protein that functions in cyclic di-GMP turnover. Proc Natl Acad Sci U S A 103:6712-6717

Sechler A, Schuenzel EL, Cooke P, Donnua S, Thaveechai N, Postnikova E, Stone AL, Schneider WL, Damsteegt VD, Schaad NW (2009) Cultivation of 'Candidatus Liberibacter asiaticus ',
'Ca. L. africanus', and 'Ca. L. americanus' associated with huanglongbing. Phytopathology 99:480-486

Siciliano F, Torres PS, Sendin L, Bermejo C, Filippone P, Vellice G, Ramallo J, Castagnaro A, Vojnov A, Marano MR (2006) Analysis of the molecular basis of Xanthomonas axonopodis pv. citri pathogenesis in Citrus limon. Electron J Biotechnol 9:200-204

Simpson AJ, Reinach FC, Arruda P, Abreu FA, Acencio M, Alvarenga R, Alves LM, Araya JE, Baia GS, Baptista CS, Barros MH, Bonaccorsi ED, Bordin S, Bove JM, Briones MR, Bueno MR, Camargo AA, Camargo LE, Carraro DM, Carrer H, Colauto NB, Colombo C, Costa FF, Costa MC, Costa-Neto CM, Coutinho LL, Cristofani M, Dias-Neto E, Docena C, El-Dorry H, Facincani AP, Ferreira AJ, Ferreira VC, Ferro JA, Fraga JS, Franca SC, Franco MC, Frohme M, Furlan LR, Garnier M, Goldman GH, Goldman MH, Gomes SL, Gruber A, Ho PL, Hoheisel JD, Junqueira ML, Kemper EL, Kitajima JP, Krieger JE, Kuramae EE, Laigret F, Lambais MR, Leite LC, Lemos EG, Lemos MV, Lopes SA, Lopes CR, Machado JA, Machado MA, Madeira AM, Madeira HM, Marino CL, Marques MV, Martins EA, Martins EM, Matsukuma AY, Menck CF, Miracca EC, Miyaki CY, Monteriro-Vitorello CB, Moon DH, Nagai MA, Nascimento AL, Netto LE, Nhani A Jr, Nobrega FG, Nunes LR, Oliveira MA, de Oliveira MC, de Oliveira RC, Palmieri DA, Paris A, Peixoto BR, Pereira GA, Pereira HA Jr, Pesquero JB, Quaggio RB, Roberto PG, Rodrigues V, de MRAJ, de Rosa VE Jr, de Sa RG, Santelli RV, Sawasaki HE, da Silva AC, da Silva AM, da Silva FR, da Silva WA Jr, da Silveira JF, Silvestri ML, Siqueira WJ, de Souza AA, de Souza AP, Terenzi MF, Truffi D, Tsai SM, Tsuhako MH, Vallada H, Van Sluys MA, Verjovski-Almeida S, Vettore AL, Zago MA, Zatz M, Meidanis J, Setubal JC (2000) The genome sequence of the plant pathogen Xylella fastidiosa. The Xylella fastidiosa Consortium of the Organization for Nucleotide Sequencing and Analysis. Nature 406:151-159

Slater H, Alvarez-Morales A, Barber CE, Daniels MJ, Dow JM (2000) A two-component system involving an HD-GYP domain protein links cell-cell signalling to pathogenicity gene expression in Xanthomonas campestris. Mol Microbiol 38:986-1003

Stall RE, Seymour CP (1983) Canker, a threat to citrus in the Gulfcoast states. Plant Dis 67:581-585

Stokstad E (2006) Agriculture. New disease endangers Florida's already-suffering citrus trees. Science 312:523-524

Sun XA, Stall RE, Jones JB, Cubero J, Gottwald TR, Graham JH, Dixon WN, Schubert TS, Chaloux PH, Stromberg VK, Lacy GH, Sutton BD (2004) Detection and characterization of a new strain of citrus canker bacteria from key Mexican lime and Alemow in South Florida. Plant Dis 88:1179-1188

Swarup S, Yang Y, Kingsley MT, Gabriel DW (1992) An Xanthomonas citri pathogenicity gene, pthA, pleiotropically encodes gratuitous avirulence on nonhosts. Mol Plant Microb Interact 5:204-213

Tang JL, Liu YN, Barber CE, Dow JM, Wootton JC, Daniels MJ (1991) Genetic and molecular analysis of a cluster of rpf genes involved in positive regulation of synthesis of extracellular enzymes and polysaccharide in Xanthomonas campestris pathovar campestris. Mol Gen Genet 226:409-417

Teixeira D (2005) First report of a huanglongbing-like disease of citrus in São Paulo State, Brazil, and association of a new Liberibacter species, 'Candidatus Liberibacter americanus', with the disease. Plant Dis 89:107

Torres PS, Malamud F, Rigano LA, Russo DM, Marano MR, Castagnaro AP, Zorreguieta A, Bouarab K, Dow JM, Vojnov AA (2007) Controlled synthesis of the DSF cell-cell signal is required for biofilm formation and virulence in Xanthomonas campestris. Environ Microbiol 9:2101-2109 
Tyler HL, Roesch LF, Gowda S, Dawson WO, Triplett EW (2009) Confirmation of the sequence of 'Candidatus Liberibacter asiaticus ' and assessment of microbial diversity in huanglongbing-infected citrus phloem using a metagenomic approach. Mol Plant Microb Interact 22:1624-1634

Van Sluys MA, Monteiro-Vitorello CB, Camargo LE, Menck CF, Da Silva AC, Ferro JA, Oliveira MC, Setubal JC, Kitajima JP, Simpson AJ (2002) Comparative genomic analysis of plantassociated bacteria. Annu Rev Phytopathol 40:169-189

Verniere C, Hartung JS, Pruvost OP, Civerolo EL, Alvarez AM, Maestri P, Luisetti J (1998) Characterization of phenotypically distinct strains of Xanthomonas axonopodis pv. citri from Southwest Asia. European J Plant Pathol 104:477-487
Wang LH, He Y, Gao Y, Wu JE, Dong YH, He C, Wang SX, Weng LX, Xu JL, Tay L, Fang RX, Zhang LH (2004) A bacterial cellcell communication signal with cross-kingdom structural analogues. Mol Microbiol 51:903-912

Whitehead NA, Barnard AM, Slater H, Simpson NJ, Salmond GP (2001) Quorum-sensing in Gram-negative bacteria. FEMS Microbiol Rev 25:365-404

Zhao X (1981) Cirtus yellow shoot disease (huanglongbing) - a review. Proc Int Soc Citriculture 1:466-469

Zhu W, Yang B, Chittoor JM, Johnson LB, White FF (1998) AvrXa10 contains an acidic transcriptional activation domain in the functionally conserved $\mathrm{C}$ terminus. Mol Plant Microb Interact $11: 824-832$ 